\title{
GROSS ANATOMY OF THE HEART OF THE INDIAN ONE HORNED RHINOCEROS (RHINOCEROS UNICORNIS)
}

\author{
M. Bhattacharya, M.V.Sc., Ph.D.* G. Baishya, M.V.Sc.* \\ A. Chakraborty, M.V.Sc. $\dagger \quad$ G. K. Baruah, M.V.Sc., Ph.D. $\dagger$
}

\begin{abstract}
The hearts of a full-term fetus and an adult Indian one horned rhinoceros were studied. Although the gross anatomical features of the rhino heart generally resembled those of the hearts of the elephant, Asiatic buffalo, goat, and other domestic animals, there were differences in the biometrics.
\end{abstract}

\section{INTRODUCTION}

The Indian one horned rhinoceros is native to Assam and now is found primarily in the world-famous wildlife sanctuaries of Kaziranga and Manas. Scientific information on this unique species is minimal. This report records the gross anatomic characteristics of the heart, with emphasis on measurements.

\section{MATERIALS AND METHODS}

The hearts of two Indian one horned rhinoceroses (one full-term fetus and an adult) were obtained from the State Zoo-cum-Botanical Garden, Gauhati. The hearts were measured and gross anatomical features were noted. Topographical observations were not possible due to prior postmortem examination.

\section{RESULTS AND DISCUSSION}

The general gross anatomy of the hearts was similar to descriptions of the hearts of the elephant, ${ }^{5}$ Asiatic buffalo, ${ }^{1,4}$ goat, ${ }^{3}$ and other domestic animals. ${ }^{2}$ Therefore, in the following description, only the differences are explained.

The heart presented two surfaces, a broad base and narrow apex; the incisura apicis cordis was marked only in the apex of the adult heart and not in the fetal heart (Fig. 1). An incisura apicis cordis was reported to be present in the heart of the pig $^{2}$ and fetal Indian elephant. ${ }^{5}$ In addition to right

\footnotetext{
* Department of Anatomy and Histology, Assam Agricultural University, Gauhati-781 022, Assam, India.

† Department of Pathology, Assam Agricultural University, Gauhati-781 022, Assam, India.
}

and left longitudinal grooves on the surfaces of the rhinoceros heart, there were one or two shorter grooves that did not reach half of the ventricular length.

Biometric features from this study are presented in Table 1 and comparative figures in Table 2. Most of the measurements of the fetal rhinoceros heart corresponded with those of the fetal Indian elephant; however, the foramen ovale in the heart of the

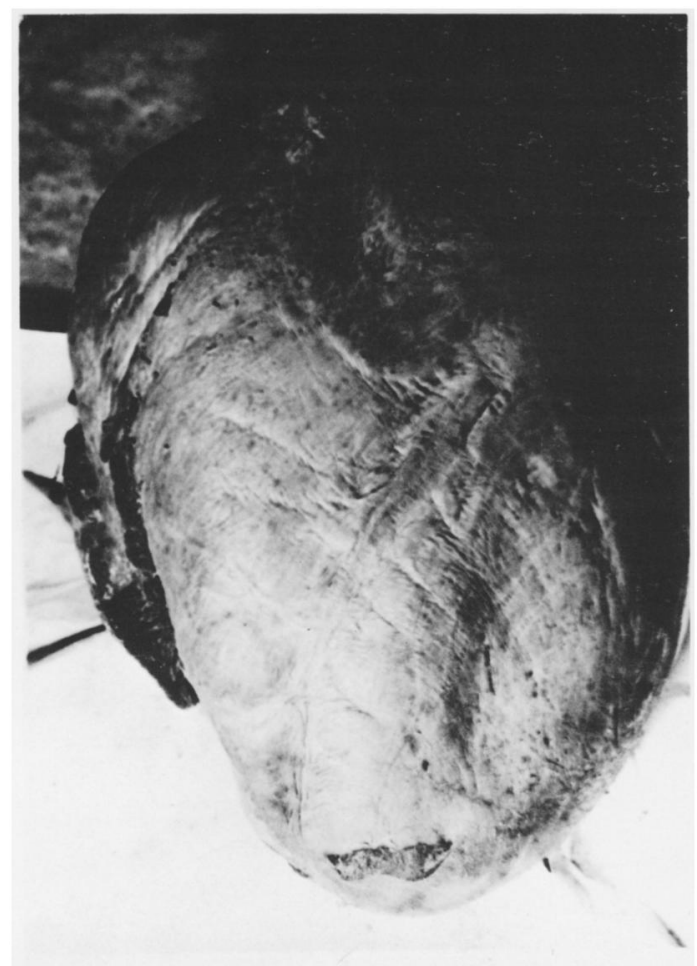

Figure 1. Incisura apicis cordis in the adult rhinoceros heart. 
Table 1. Measurements of the heart of rhinoceros.

\begin{tabular}{|c|c|c|c|c|c|}
\hline \multirow[t]{2}{*}{$\begin{array}{l}\text { Sl. } \\
\text { no. }\end{array}$} & \multirow[t]{2}{*}{ Parameter } & \multicolumn{4}{|c|}{ Measurement } \\
\hline & & \multicolumn{2}{|c|}{ Fetus } & \multicolumn{2}{|c|}{ Adult } \\
\hline 1. & Weight (kg) & \multicolumn{2}{|c|}{0.250} & \multicolumn{2}{|c|}{9.5} \\
\hline \multirow[t]{3}{*}{2.} & Length (base to apex) (cm) & \multicolumn{2}{|c|}{11.3} & \multicolumn{2}{|c|}{32.2} \\
\hline & & \multicolumn{2}{|c|}{ Right atrium } & \multicolumn{2}{|c|}{ Left atrium } \\
\hline & & Fetus & Adult & Fetus & Adult \\
\hline 3. & Longitudinal length $(\mathrm{cm})$ & 5.8 & 22 & 5 & 24 \\
\hline 4. & Width at widest part $(\mathrm{cm})$ & 3.6 & 8.4 & 2.5 & 10.2 \\
\hline 5 . & $\begin{array}{l}\text { Wall thickness at smooth } \\
\text { part }(\mathrm{cm})\end{array}$ & 0.5 & 1.9 & 0.4 & 2 \\
\hline 6. & $\begin{array}{l}\text { Diameter of cranial vena } \\
\text { cava }(\mathrm{cm})\end{array}$ & 3.6 & 10.6 & - & - \\
\hline 7. & $\begin{array}{l}\text { Diameter of caudal vena } \\
\text { cava }(\mathrm{cm})\end{array}$ & 2.7 & 6.2 & - & - \\
\hline 8. & $\begin{array}{l}\text { Thickness of prominent } \\
\text { musculae pectinatae }(\mathrm{cm})\end{array}$ & 0.7 & 1.3 & - & - \\
\hline \multirow[t]{4}{*}{9.} & $\begin{array}{l}\text { Diameter of pulmonary } \\
\text { vein }(\text { at root })(\mathrm{cm})\end{array}$ & & & & \\
\hline & Small & - & - & 0.3 & 1.8 \\
\hline & Medium & - & - & 0.8 & 3.8 \\
\hline & Large & - & - & 2.0 & 6.5 \\
\hline 10. & $\begin{array}{l}\text { Diameter of foramen ovale } \\
\text { a) Transverse } \\
\text { b) Vertical }\end{array}$ & $\begin{array}{l}1.7 \\
2.4\end{array}$ & Absent & - & - \\
\hline \multirow[t]{3}{*}{11.} & $\begin{array}{l}\text { Diameter of pulmonary } \\
\text { trunk at root }(\mathrm{cm})\end{array}$ & $1.9^{*}$ & $3.8^{*}$ & - & - \\
\hline & & \multicolumn{2}{|c|}{ Right longitudinal groove } & \multicolumn{2}{|c|}{ Left longitudinal groove } \\
\hline & & Fetus & Adult & Fetus & Adult \\
\hline \multirow[t]{2}{*}{12.} & Length $(\mathrm{cm})$ & $\begin{array}{c}5.5 \\
\text { (straight, and } \\
1.9 \mathrm{~cm} \text { away } \\
\text { from the } \\
\text { point of } \\
\text { apex) }\end{array}$ & $\begin{array}{c}20.5 \\
\text { (does not } \\
\text { reach apex) }\end{array}$ & $\begin{array}{c}9.0 \\
\text { (curved and } \\
2.3 \mathrm{~cm} \text { away } \\
\text { from apex) }\end{array}$ & 41.0 \\
\hline & & \multicolumn{2}{|c|}{ Fetus } & \multicolumn{2}{|c|}{ Adult } \\
\hline \multirow[t]{4}{*}{13.} & $\begin{array}{l}\text { Ventricular valve } \\
\text { Cusp of right ventricle } \\
\text { (attached to free } \\
\text { margin) }(\mathrm{cm})\end{array}$ & \multicolumn{2}{|c|}{2.0} & \multicolumn{2}{|c|}{$\begin{array}{c}5.2 \\
(1.3 \mathrm{~cm} \text { at shortest part) }\end{array}$} \\
\hline & $\begin{array}{l}\text { Cusp of left ventricle } \\
\text { (attached to free } \\
\text { margin) }(\mathrm{cm})\end{array}$ & \multicolumn{2}{|c|}{1.9} & $(1.1 \mathrm{~cm} \mathrm{at}$ & est part) \\
\hline & $\begin{array}{l}\text { Cusp of pulmonary valve } \\
(\mathrm{cm})\end{array}$ & \multicolumn{2}{|c|}{1.1} & \multicolumn{2}{|c|}{3.2} \\
\hline & $\begin{array}{l}\text { Cusp of aortic valve } \\
(\mathrm{cm})\end{array}$ & \multicolumn{2}{|c|}{1.1} & \multicolumn{2}{|c|}{3.2} \\
\hline \multirow[t]{3}{*}{14.} & Ventricular wall thickness & \multirow{3}{*}{\multicolumn{2}{|c|}{$\begin{array}{l}1.0 \\
1.6\end{array}$}} & \multirow{2}{*}{\multicolumn{2}{|c|}{4.0}} \\
\hline & Right & & & & \\
\hline & Left & & & & \\
\hline
\end{tabular}


Table 1. Continued

\begin{tabular}{|c|c|c|c|}
\hline $\begin{array}{l}\text { Sl. } \\
\text { no. }\end{array}$ & Parameter & \multicolumn{2}{|c|}{ Measurement } \\
\hline & & Fetus & Adult \\
\hline 15. & $\begin{array}{l}\text { Thickness of } \\
\text { Pulmonary artery } \\
\text { Aorta } \\
\text { Pulmonary vein }\end{array}$ & $\begin{array}{l}0.1 \\
1.3 \\
0.4\end{array}$ & $\begin{array}{l}0.8 \\
2.2 \\
0.5\end{array}$ \\
\hline 16. & Septal thickness & 1.0 & 7.0 \\
\hline
\end{tabular}

${ }^{*}$ From right ventricle.

Table 2. Comparative measurements of the heart.

\begin{tabular}{|c|c|c|c|c|c|c|}
\hline $\begin{array}{l}\text { Sl. } \\
\text { no. }\end{array}$ & Species & $\begin{array}{l}\text { Sagittal } \\
\text { diameter } \\
\text { of base } \\
\text { (cm) }\end{array}$ & $\begin{array}{l}\text { Greater } \\
\text { width of } \\
\text { base } \\
(\mathrm{cm})\end{array}$ & $\begin{array}{l}\text { Circumference } \\
\text { at coronary } \\
\text { groove } \\
\text { (cm) }\end{array}$ & $\begin{array}{l}\text { Distance } \\
\text { between } \\
\text { pulmonary } \\
\text { artery } \\
\text { and apex } \\
\text { (cm) }\end{array}$ & $\begin{array}{c}\text { Distance } \\
\text { between } \\
\text { termination } \\
\text { of caudal } \\
\text { vena cava } \\
\text { and apex } \\
\text { (cm) }\end{array}$ \\
\hline \multicolumn{7}{|c|}{ 1. Rhino (present study) } \\
\hline & Fetus & 11.3 & 8.1 & 20 & 11.5 & 10 \\
\hline & Adult & 32.2 & 27 & 68 & 34 & 26 \\
\hline & Buffalo 4 & 16.40 & 14.35 & 38.75 & 17.95 & 14.45 \\
\hline & Buffalo $^{1}$ & $17-20$ & $13-15$ & $55-60$ & $22-23$ & $19-20$ \\
\hline & $O x^{2}$ & - & 12 & 38 & 17 & - \\
\hline & Horse $^{6}$ & 25 & $18-20$ & $65-70$ & 25 & $18-20$ \\
\hline & Goat $^{4}$ & 8.52 & 4.94 & 13.83 & 8.15 & 6.48 \\
\hline
\end{tabular}

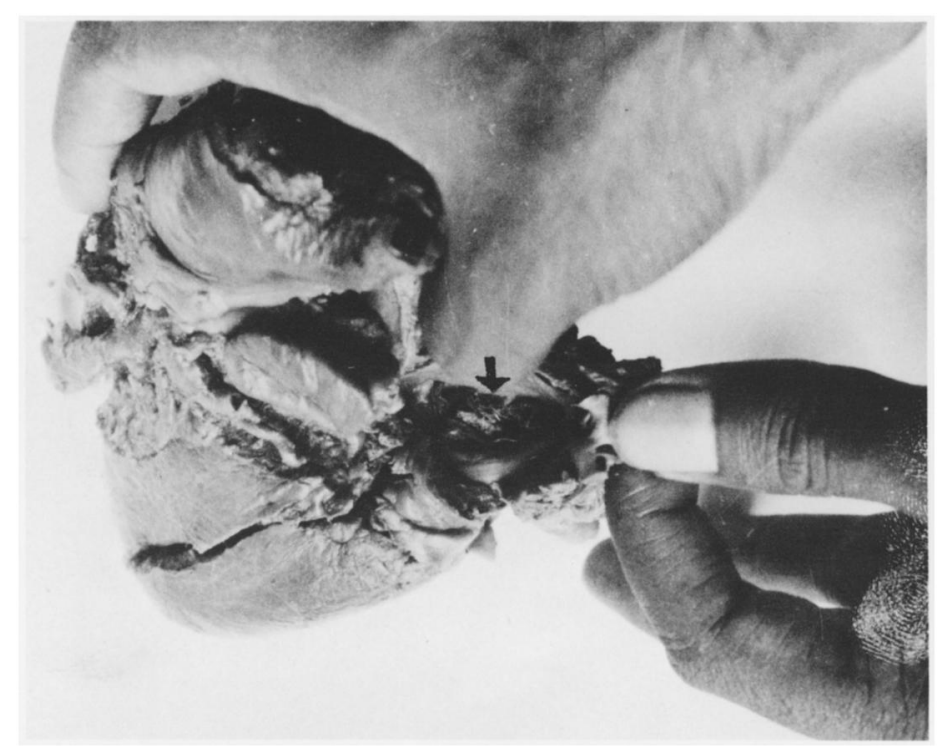

Figure 2. Presence of foramen ovale (arrow) in the fetal rhinoceros heart. 
fetal elephant had a transverse diameter of $1.0 \mathrm{~cm}$ and vertical diameter of $1.5 \mathrm{~cm}$, while the size of foramen ovale in the heart of the rhinoceros fetus was larger (Fig. 2). The thickness of the ventricular septum in the fetal Indian elephant $(2.5 \mathrm{~cm})$ was higher than in the fetal rhinoceros. The aortic valve consisted of three cusps, with the anterior sinus having a prominent nodule. There were right and left coronary arteries similar to those of domestic animals. ${ }^{2}$ The elephant is different in that one of the coronary arteries is subdivided into two major branches. ${ }^{5}$

The course of coronary arteries in the rhinoceros heart differed from that in domestic animals. The left coronary artery $(0.6 \mathrm{~cm}$ at the root) originated from the left posterior sinus, and had a descending branch at the left longitudinal groove and smaller branches, one of which anastomosed with a branch of the right coronary artery. The right cor- onary artery $(0.8 \mathrm{~cm}$ at the root $)$ originated from the anterior sinus and continued in the coronary groove with additional branching.

\section{REFERENCES}

1. Dhingra, L. D. and Sharma, D. N.: Topographic anatomy of the heart of adult female Murrah buffalo (Bubalus bubalis). Indian Journal of Animal Science 48(10): 729-736, 1978.

2. Ghoshal, W. G.: Heart and arteries. Cited in: Getty, R.: Sisson and Grossman's anatomy of domestic animals. Philadelphia: W. B. Saunders Co., 1975.

3. Malik, M. R., Shrivastava, A. M. and Thakur, M. S.: A note on the biometry of caprine heart. Indian Journal of Animal Science 48(9): 686-687, 1978.

4. Malik, M. R., Tewari, G. P., Singh, A. P. and Kapoor, P. N.: Biometry of the heart of the buffalo (Bubalus bubalis). Indian Journal of Animal Science 42: 1004-1006, 1972.

5. Mariappa, D.: The anatomy of the fetal Indian elephant. Indian Veterinary Journal 35: 191-208, 251$267,1958$.

6. Sisson, S. and Grossman, J. D.: The anatomy of the domestic animals. Philadelphia: W. B. Saunders Co., 1953. 